\title{
Facts and alternative facts - basic principles of scientific work
}

\author{
Julia Mascherbauer
}

Published online: 28 March 2017

(C) Springer-Verlag Wien 2017

The term "alternative facts" was heavily discussed recently. Kellyanne Conway, advisor to President Trump, used it during an interview when the claim of Trump's press secretary Sean Spicer, that record high numbers of people had attended Trumps inauguration as President, was discussed. This claim was identified as being false but Conway insisted that Spicer had only been offering "alternative facts". Since then, a hot discussion has been led about "alternative facts" and falsehoods, and the difference between those two.

Particularly in science, a clear cut line between facts and untruth should be strived for; however, as long as "alternative facts" are offered as an alternative, a theory, is there anything wrong about them? Sir Karl Popper, one of the greatest philosophers of science of the twentieth century, rejected the classical inductivist views on the scientific method, which are characterized by generalization of observed patterns that are confirmed by many observations. Popper argued that science should use a methodology based on falsifiability, because no number of experiments can ever prove a theory, but a single experiment can contradict one [1].

In law "alternative facts" describe inconsistent sets of facts put forth in a court given that there is plausible evidence to support both alternatives. The term is also used to describe competing facts for the two sides of the case [2].

In medicine, it is not uncommon that new therapies are established based solely on reasonable pathophysiological concepts and results of small studies or registries; however, after years of application, large

J. Mascherbauer, MD ( $\bowtie)$

Section Editor Cardiology, Department of Internal

Medicine II, Divisions of Cardiology, Medical University of

Vienna, Waehringer Guertel 18-20, 1090 Vienna, Austria

julia.mascherbauer@meduniwien.ac.at prospective randomized clinical trials may eventually contradict such long-term practice. Most doctors and medical scientists are aware of several cases. Recent examples from the cardiovascular field are "intraaortic balloon support for myocardial infarction with cardiogenic shock" [3, 4], "thrombus aspiration during ST-segment elevation myocardial infarction" $[5,6]$ and "renal denervation in patients with uncontrolled hypertension" [7]. Based on data from registries and small, non-randomized studies treatments and interventions were applied and even strongly recommended according to the respective guidelines; however, finally, large prospective randomized controlled trials demonstrated no reduction in mortality and/or morbidity [3-7]. These trials were testing "alternative facts", and falsified previously established "facts". So what is wrong about "alternative facts" or the search for them? Nothing, after all.

Almost 20 years ago, David Isaacs published an excellent paper on "Seven alternatives to evidence based medicine" [8]. Although clinical decisions should, as far as possible, be evidence based, every clinician will frequently be confronted with cases where there is no evidence on which to base the decision. In such situations, clinical decisions may be based on the faith in the opinion of a very experienced senior college (or head of department) or the belief in the most vehement or the most (self-)confident discussant; however, the preferred alternative would be to test "alternative facts" and probably falsify various theories in well-designed studies.

Editors and reviewers of scientific journals are bound to carefully consider manuscripts that propose or investigate "alternative facts" and wage them against established dogmas. Great innovations often arise from a complete wrap-up of traditional attitudes and patterns of thought. 
In this spirit I encourage investigators to pursue the search for "alternative facts" but at the same time uphold the codex of science: honesty, precision, and truth [9].

Conflict of interest J. Mascherbauer declares that she has no competing interests.

\section{References}

1. Popper K. The logic of science discovery. New York: Basic Books; 1959.

2. https://en.wikipedia.org/wiki/Alternative_facts_(law). Last access: 23.03.2017

3. Thiele H, Zeymer U, Neumann FJ, Ferenc M, Olbrich HG, Hausleiter J, Richardt G, Hennersdorf M, Empen K, Fuernau G, Desch S, Eitel I, Hambrecht R, Fuhrmann J, Böhm M, Ebelt H, Schneider S, Schuler G, Werdan K, IABPSHOCK II Trial Investigators. Intraaortic balloon support for myocardial infarction with cardiogenic shock. N Engl J Med. 2012;367(14):1287-96.

4. Thiele H, Zeymer U, Neumann FJ, Ferenc M, Olbrich HG, Hausleiter J, deWaha A, Richardt G, Hennersdorf M, Empen K, Fuernau G, Desch S, Eitel I, Hambrecht R, Lauer B, Böhm M, Ebelt H, Schneider S, Werdan K, Schuler G. Intraaortic Balloon Pump in cardiogenic shock II (IABP-SHOCK II) trial investigators. Intra-aortic balloon counterpulsation in acute myocardial infarction complicated by cardiogenic shock (IABP-SHOCK II): final 12 month results of a randomised, open-labeltrial. Lancet. 2013;382(9905):1638-45.

5. Frobert O, Lagerqvist B, Olivecrona GK, Omerovic E, Gudnason T, Maeng M, Aasa M, Angerås O, Calais F, Danielewicz M, Erlinge D, Hellsten L, Jensen U, Johansson AC, Kåregren A, Nilsson J, Robertson L, Sandhall L, Sjögren I, Ostlund O, Harnek J, James SK, TASTE Trial. Thrombus aspiration during ST-segment elevation myocardial infarction. NEngl JMed. 2013;369:1587-97.

6. Jolly SS, Cairns JA, Yusuf S, Meeks B, Pogue J, Rokoss MJ, Kedev S, Thabane L, Stankovic G, Moreno R, Gershlick A, Chowdhary S, Lavi S, Niemelä K, Steg PG, Bernat I, Xu Y, Cantor WJ, Overgaard CB, Naber CK, Cheema AN, Welsh RC, Bertrand OF, Avezum A, Bhindi R, Pancholy S, Rao SV, Natarajan MK, ten Berg JM, Shestakovska O, Gao P, Widimsky P, Džavík V. Randomized trial of primary PCI with or without routine manual thrombectomy. N Engl J Med. 2015(15);372:1389-98.

7. Bakris GL, Townsend RR, Liu M, Cohen SA, D'Agostino R, Flack JM, Kandzari DE, Katzen BT, Leon MB, Mauri L, Negoita M, O'Neill WW, Oparil S, Rocha-Singh K, Bhatt DL, SYMPLICITY HTN-3 Investigators. Impact of renal denervation on 24-hour ambulatory blood pressure: results from SYMPLICITYHTN-3. JAmCollCardiol. 2014;64(11):1071-8.

8. Isaacs D, Fitzgerald D. Seven alternatives to evidence based medicine. BMJ. 1999;319(7225):1618.

9. Lüscher TF. The codex of science: honesty, precision, and truth-and its violations. Eur Heart J.2013;34(14):1018-23. 